\title{
Host preference of Thrips hawaiiensis for different ornamental plants
}

\author{
Yu Cao ${ }^{1}$. - Stuart R. Reitz ${ }^{2}$. Giacinto Salvatore Germinara ${ }^{3}$. Chun Wang ${ }^{1} \cdot$ Lijuan Wang $^{1} \cdot$ Siyu Yang ${ }^{1}$. Yulin Gao ${ }^{4}$. \\ Wenqing Zhang ${ }^{5} \cdot$ Can Li $^{1}$
}

Received: 21 September 2020 / Revised: 9 June 2021 / Accepted: 10 June 2021 / Published online: 22 June 2021

(c) The Author(s) 2021

\begin{abstract}
Thrips hawaiiensis is a common thrips pest that damages the flowers of various plants. The differing population sizes of $T$. hawaiiensis among host plants suggest its preference and performance vary among host plants. In this study, the host fitness of $T$. hawaiiensis for different flowers was assessed through field investigation. The behavioral responses of T. hawaiiensis to the color and volatiles of flowers eliciting different apparent fitness levels and their development and survival on the plants were also studied. Adults and larvae of T. hawaiiensis were found in the flowers of 21 species, which were classified into four fitness levels for this thrips species. T. hawaiiensis showed significantly different visual responses to the color and olfactory responses to the volatiles of four tested flowers (each representing one of the four fitness levels), with the rankings of visual preferences for Dianthus caryophyllus $>$ Tulipa gesneriana $>$ Hydrangea macrophylla $>$ Rosa rugosa, and olfactory preferences for $H$. macrophylla $\geq T$. gesneriana $>$ D. caryophyllus $>R$. rugosa. Plant species had significant influences on the development and survival of $T$. hawaiiensis, with developmental times from egg to adult of $9.58 \mathrm{~d}, 9.92 \mathrm{~d}, 10.35 \mathrm{~d}$ and $10.75 \mathrm{~d}$ on $H$. macrophylla, T. gesneriana, D. caryophyllus and R. rugosa, respectively, and corresponding survival rates of $76.33 \%, 71.33 \%, 64.00 \%$ and $59.00 \%$. In summary, this study shows that olfactory preferences were consistent with the field performance of $T$. hawaiiensis on the four flower plants tested. Further, fitness levels of host plant flowers are correlated with development rate and survivorship of T. hawaiiensis. Our study adds to the understanding of the mechanism of host selection by thrips and provides basic information to underpin the management of T. hawaiiensis on horticultural plants.
\end{abstract}

Keywords Thrips hawaiiensis $\cdot$ Field investigation $\cdot$ Host plant preference $\cdot$ Behavioral responses $\cdot$ Development $\cdot$ Survival

Communicated by Antonio Biondi.

Yu Cao

yucaosuccess@126.com

$\triangle \mathrm{Can} \mathrm{Li}$

lican790108@163.com

1 Guizhou Provincial Key Laboratory for Rare Animal and Economic Insect of the Mountainous Region, Guizhou Provincial Engineering Research Center for Biological Resources Protection and Efficient Utilization of the Mountainous Region, Department of Biology and Engineering of Environment, Guiyang University, Guiyang, China

2 Department of Crop and Soil Sciences, Malheur County Extension, Oregon State University, Ontario, OR, USA

3 Department of Agricultural Sciences, Natural and Engineering, University of Foggia, FoodFoggia, Italy

4 State Key Laboratory for Biology of Plant Diseases and Insect Pests, Institute of Plant Protection, Chinese Academy of Agricultural Sciences, Beijing, China

5 State Key Laboratory of Biocontrol and School of Life Sciences, Sun Yat-Sen University, Guangzhou, China

\section{Key message}

- 21 flowering host plant species were classified at four fitness levels by $T$. hawaiiensis.

- Fitness levels were consistent with olfactory preferences, not visual preferences, of thrips.

- Thrips' development and survival rates were higher on flowers with higher fitness levels.

- Our results shed light on the host selection mechanism of T. hawaiiensis.

- These findings will be useful for devising strategies to control this thrips pest. 


\section{Introduction}

Thrips hawaiiensis (Morgan) (Thysanoptera: Thripidae) is a common flower-dwelling thrips (Mound 2005) that is native to Oriental and Pacific regions. Through increasing international trade, it has expanded its geographical range to Africa, Australia, Europe, and America (Reynaud et al. 2008; Goldarazena 2011; Atakan et al. 2015). T. hawaiiensis has a wide host range among crops, including various fruits, vegetables and ornamental plants (Murai 2001; Aliakbarpour and Salmah 2011; Cao et al. 2018). Thus, $T$. hawaiiensis is becoming a more important agricultural and horticultural pest worldwide, particularly in many provinces of China. It is a dominant thrips pest on banana and mango and results in large annual economic losses through yield reductions (Wu et al. 2014, Fu et al. 2018).

Thrips hawaiiensis prefers to feed and live in flowers, rather than in other plant structures (Murai 2001; Mound 2005; Fu et al. 2020). Different population sizes and associated degrees of damage have been found on different host plant species (Huang et al. 2009; Cao et al. 2018). These differences in populations indicate that T. hawaiiensis exercises host preferences in the field.

For thrips, host orientation and selection is driven by visual and olfactory cues (Vernon and Gillespie 1990, 1995; Teulon et al. 1999; Pearsall 2000; Cao et al. 2019). The rates of, for example, development, survival, and oviposition vary significantly when different plant species are supplied as food sources (Brown et al. 2003; Li et al. 2015; Cao et al. 2018). Thrips also show different physiological responses to different host plants. Frankliniella occidentalis (Pergande) and $F$. intonsa (Trybom) have significantly different activities of detoxifying enzymes and protective enzymes when feeding on different host species (Liu et al. 2017). Therefore, both behavioral and physiological responses of thrips to the physical and chemical properties of plant species affect host selection and performance of these insects.

In this study, the host suitability of flowering plants for $T$. hawaiiensis was assessed through field investigation in the Guiyang area, Guizhou Province, China. In conjunction with field observations, further research was conducted on how fitness is related to the host preferences of $T$. hawaiiensis. Thus, we studied the visual responses to color, olfactory responses to volatiles, and the development and survival of thrips on different host plants with different levels of fitness, as determined in the field investigations. The results of this study help to explain the differences in the extent of damage caused by $T$. hawaiiensis among different host plants, and provide basic data to explore the host selection mechanisms of this thrips species. Ultimately, this information will be useful for devising targeted strategies to control of this pest on particular horticultural plants.

\section{Materials and methods}

\section{Host associated fitness of T. hawaiiensis under field conditions}

Field sampling was undertaken in Guiyang area, Guizhou Province, China, from April 2015 to December 2016, during the early, middle and late period of each month. No pesticides were used in the sampling areas. In total, 10 main locations were selected for sample collection, with necessary changes according to the richness of plant species in the flowering stage in different sampling periods. All the flowers present in each sampling area were sampled, so all of the flowering plants in Nanming district, Guiyang, China, were included in our study. Each sampling area was approximately $400 \mathrm{~m}^{2}$, and a five-point sampling method was used. The center of the diagonals and four points equidistant to this point were fixed as sampling sites. Two plants were selected per host at each location. The number of adults of T. hawaiiensis were counted in six flowers in total per plant, two collected from the lower, middle and upper part of the plant, respectively. These flowers were taken to the laboratory to allow eggs to hatch. The emerged larvae were reared in plastic containers $(20 \times 14 \times 9 \mathrm{~cm})$ with snap-on lids, in climate-controlled rooms at $26 \pm 1{ }^{\circ} \mathrm{C}, 70 \pm 5 \%$ relative humidity (RH), under a 14:10 h light/dark photoperiod (Cao et al. 2014). The larvae were fed with the flowers of the plant they were collected from until they reached the adult stage. All of the adult thrips were identified under a microscope (Olympus CX41, ZSA300) to evaluate the proportion of $T$. hawaiiensis (Cao et al. 2018, 2019).

A selectivity index $(I)$ and suitability index $(P)$ were used to evaluate the host fitness for T. hawaiiensis (Yuan et al. 2011; Cao et al. 2019), and were calculated as follows:

$I=N / M$

$P=I \times\left(L_{a}+L_{A}\right) / 100$

where $\mathrm{N}$ is the number of times T. hawaiiensis was found on each flowering host plant, $\mathrm{M}$ is the total number of investigation times for each host plant, and La and LA are the largest numbers of, respectively, larvae and adults (male and female combined) of $T$. hawaiiensis observed among all replicates of each host plant. For each plant species, the number of thrips per flower was used to assess the host fitness for $T$. hawaiiensis, but the influence of flower size was not considered among different plants. The host plants were classified into different fitness levels for T. hawaiiensis, as measured using the method described by Bo et al. (1997) and Yuan et al (2011), which are based on the comparison between the $P$ value of each plant flower and $\mathrm{X}$ (the mean value of $P$ for all the flower species). The most suitable host plants (****) 
$(P \geq 2 \mathrm{X})$, suitable host plants $(* * *)(\mathrm{X} \leq P<2 \mathrm{X})$, relatively suitable host plants $(* *)(\mathrm{X} / 2 \leq P<\mathrm{X})$, and least-suitable host plants $(*)(P<\mathrm{X} / 2)$.

\section{Insects and plants}

Thrips hawaiiensis adults were collected from various plant species in Guiyang area, Guizhou Province, China, and used to establish laboratory colonies. These thrips were transferred onto green bean pods Phaseolus vulgaris L. (Fabales: Leguminosae $)$ in plastic containers $(20 \times 14 \times 9 \mathrm{~cm})$ with snap-on lids. A hole $(5 \mathrm{~cm} \times 4 \mathrm{~cm})$ was cut in the lid and covered with thrip-proof organdy (40- $\mu \mathrm{m}$ mesh) to allow for ventilation (Cao et al. 2014). The thrips were kept in a climate-controlled room at $26 \pm 1{ }^{\circ} \mathrm{C}, 70 \pm 5 \% \mathrm{RH}$, under a $14 \mathrm{~L}: 10 \mathrm{D}$ h photoperiod. Subsequent colonies were reared continuously for more than five generations before being used in bioassays.

The flowering plants used in these experiments were determined to be hosts of $T$. hawaiiensis with different fitness levels in our field investigation. The species used were Hydrangea macrophylla L. (Saxifragales: Saxifragaceae), Tulipa gesneriana L. (Liliales: Liliaceae), Dianthus caryophyllus L. (Caryophyllales: Caryophyllaceae), and Rosa rugosa Thunb. (Rosales: Rosaceae). Plants were grown in greenhouses in the nursery of Guiyang University, Guizhou Province, China (Cao et al. 2018). Greenhouses were maintained free of insect pests by insect-proof netting, and plants were cultivated without application of insecticides. Plants were sampled at the same flowering stage. Flowers at anthesis with intact petals were collected for olfactory tests and investigation of development and survival of thrips.

\section{Free choice of flower color by thrips}

Colored paper was used to create different visual stimulations (Cai et al. 2015) using the RGB color mode of Byers (2006). The paper samples were purple (RGB: 128, 0, 128), yellow (RGB: 255, 255, 0), white (RGB: 255, 255, 255) or pink (RGB: 255, 192, 203), similar colors to the flowers of $H$. macrophylla, T. gesneriana, D. caryophyllus and $R$. rugosa, respectively. The selectivity of $T$. hawaiiensis among the colors was tested in plastic Petri dishes (diameter $15 \mathrm{~cm}$ ), using the method of Pang et al. (2004) and Tian et al. (2017) with necessary modifications. A circle (diameter $1 \mathrm{~cm}$ ) was drawn in the center of the bottom of each Petri dish, and a "+" shape that filled in the whole dish was drawn through the center of the circle to divide the dish into four quadrants. Paper of the different colors was cut into small circles (diameter $3 \mathrm{~cm}$ ), and one of four different papers was placed in each quadrant. T. hawaiiensis 2-3-day-old adults after emergence were starved for $6 \mathrm{~h}$ before bioassays and then introduced in groups of ca. 80 individuals into the Petri dish through a hole (diameter $0.5 \mathrm{~cm}$ ) in the center of the dish cover. After 30 min the number of thrips on each of the different colored papers was counted; thrips in the center of the dish (a circle with diameter $3 \mathrm{~cm}$ ) were considered as not having chosen a particular color. The paper locations were rotated $\left(90^{\circ}\right)$ after each test to minimize positional effects, and the color paper randomized within each dish. Bioassays were replicated four times, and all were carried out between 09:00 and 17:00. Each replicate contained three dishes. Females and males $T$. hawaiiensis were tested separately.

\section{Olfactory responses of thrips}

The olfactory responses of $T$. hawaiiensis to the volatiles of different plant flowers were tested in a Y-tube olfactometer by the method of Cao et al. (2014, 2019). In these tests, we made two types of two-way comparisons: (1) each flower (no leaves or stems) vs. clean air (CA), and (2) all possible flower pairings. For each comparison, 60 T. hawaiiensis (2-3-day-old) were tested individually. Compared with male T. hawaiiensis, females are more sensitive in responding to the volatiles from host plants (Cao et al. 2020), thus only female thrips were used in these tests. Thrips were starved for $3 \mathrm{~h}$ before testing, and the flower material $(15 \mathrm{~g})$ was replaced after every 10 individuals tested. A thrips was considered to have made a choice when it crossed $2 / 3$ of one arm within $5 \mathrm{~min}$. Otherwise, the thrips was considered to be non-responding. Airflow through each arm of the olfactometer was maintained at $300 \mathrm{ml} / \mathrm{min}$ (Cao et al. 2014, 2019). All bioassays were conducted between 08:00 and 18:00.

\section{Development and survival of thrips}

Flowers of each host plant were placed in plastic containers $(20 \times 14 \times 9 \mathrm{~cm})$ with snap-on lids. A group of ca. 150 adult thrips (female: male $=1: 1$ ) was placed in each container to allow oviposition for $24 \mathrm{~h}$ (Cao et al. 2014). Because eggs are laid inside the flower tissue and are not visible, their mortality could not be determined. Newly emerged larvae were placed on fresh flower disks, as described by Gaum et al. (1994) and Van Rijn et al. (1995) with modifications (Cao et al. 2018). The development from egg to adult of T. hawaiiensis was observed daily, and juvenile survival was assessed every $12 \mathrm{~h}$. Developmental periods of eggs were determined by recording the time until the appearance of larvae (Van Rijn et al. 1995; Zhang et al. 2007). One hundred first instars were counted for each plant species as initial observation number; one larva being placed on each flower disk. This was replicated three times with total of 300 
larvae tested per type of flower. These investigations were conducted at $26 \pm 1{ }^{\circ} \mathrm{C}, 70 \pm 5 \% \mathrm{RH}$, and a $14: 10 \mathrm{~h}(\mathrm{~L}: \mathrm{D})$ photoperiod.

\section{Statistical analysis}

Data were analyzed using SPSS software (version 18.0; SPSS, Chicago, IL, USA). Data were checked for normality and homoscedasticity before further analyses. Statistically significant differences $(P<0.05)$ in the color selectivity, developmental time, and survival rate of thrips among different flowers were analyzed by one-way analysis of variance (ANOVA) and Tukey's test. The null hypothesis that T. hawaiiensis adults showed no preference for either Y-tube arm (a response equal to 50:50) was analyzed using a chisquare goodness-of-fit test.

\section{Results}

\section{Host associated fitness of T. hawaiiensis under field conditions}

In our field investigations, we found that $T$. hawaiiensis occurred on 21 plant species with different population sizes, indicating differential host preferences by the thrips (Table 1). Host fitness of these flowers for T. hawaiiensis was measured quantitatively using the selectivity index $(I)$ and suitability index $(P)$. The highest value of $I$ was 1 , and was recorded for three flower species, namely $H$. macrophylla, Gardenia jasminoides Ellis, and T. gesneriana. The lowest value of $I$ was 0.27 , which was recorded for Paeonia suffruticosa Andr. The highest $P$ value was 0.87 for $G$. jasminoides, and the lowest was 0.01 for $P$. suffruticosa. The host plants were classified at four fitness levels for $T$. hawaiiensis based on the comparison between the $P$ value of each plant flower and $\mathrm{X}$ for 0.16 (the mean value of $P$ for all the investigated flower species). The most suitable host plants comprised two species $(P \geq 2 \mathrm{X}), G$. jasminoides $(P=0.87)$ and $H$. macrophylla $(P=0.65)$. Suitable host plants comprised three species $(\mathrm{X} \leq P<2 \mathrm{X}), T$. gesneriana $(P=0.30)$, Gerbera jamesonii Bolus $(P=0.33)$, and Telosma cordata (Burm. F.) Merrill $(P=0.28)$. Relatively suitable
Table 1 Host fitness for $T$. hawaiiensis based on field investigation

\begin{tabular}{lllllll}
\hline Number & Host & $I$ & $L_{a}$ & $L_{A}$ & $P$ & Fitness \\
\hline 1 & Gardenia jasminoides & 1 & 32 & 55 & 0.87 & $* * * *$ \\
2 & Hydrangea macrophylla & 1 & 16 & 49 & 0.65 & $* * * *$ \\
3 & Tulipa gesneriana & 1 & 9 & 21 & 0.30 & $* * *$ \\
4 & Gerbera jamesonii & 0.78 & 15 & 27 & 0.33 & $* * *$ \\
5 & Telosma cordata & 0.9 & 11 & 20 & 0.28 & $* * *$ \\
6 & Dianthus caryophyllus & 0.77 & 3 & 10 & 0.10 & $* *$ \\
7 & Tagetes erecta & 0.67 & 5 & 8 & 0.09 & $* *$ \\
8 & Impatiens balsamina & 0.67 & 5 & 9 & 0.09 & $* *$ \\
9 & Dahlia pinnata & 0.38 & 12 & 21 & 0.12 & $* *$ \\
10 & Bougainvillea spectabilis & 0.48 & 5 & 15 & 0.10 & $* *$ \\
11 & Lilium brownii & 0.71 & 4 & 9 & 0.09 & $* *$ \\
12 & Rosa rugosa & 0.38 & 2 & 6 & 0.03 & $*$ \\
13 & Rosa chinensis & 0.4 & 3 & 7 & 0.04 & $*$ \\
14 & Salvia splendens & 0.42 & 5 & 6 & 0.05 & $*$ \\
15 & Rhododendron simsii & 0.25 & 1 & 6 & 0.02 & $*$ \\
16 & Paeonia suffruticosa & 0.20 & 2 & 2 & 0.01 & $*$ \\
17 & Canna indica & 0.31 & 3 & 4 & 0.02 & $*$ \\
18 & Dendranthema morifolium & 0.62 & 2 & 5 & 0.04 & $*$ \\
19 & Pelargonium hortorum & 0.25 & 2 & 5 & 0.02 & $*$ \\
20 & Malva sinensis & 0.35 & 2 & 4 & 0.02 & $*$ \\
21 & Pharbitis nil & 0.5 & 2 & 8 & 0.05 & $*$ \\
\hline & & & 25 &
\end{tabular}

$I$ is the selectivity index $(I), P$ is the suitability index $(P)$, and $L_{a}$ and $L_{A}$ are the largest numbers of larvae and adults (male and female combined), respectively, of $T$. hawaiiensis observed among all replicates of each host plant 
host plants comprised six species $(\mathrm{X} / 2 \leq P<\mathrm{X})$, Tagetes erecta L. $(P=0.09), D$. caryophyllus $(P=0.10)$, Impatiens balsamina L. $(P=0.09)$, Dahlia pinnata Cav. $(P=0.12)$, Bougainvillea spectabilis Willd. $(P=0.10)$, and Lilium brownii FE Brown $(P=0.09)$. Least-suitable host plants comprised ten species $(P<\mathrm{X} / 2)$, Rosa rugosa $(P=0.03)$, Rosa chinensis Jacq. $(P=0.04)$, Salvia splendens Ker-Gawler $(P=0.05)$, Rhododendron simsii Planch $(P=0.02), P$. suffruticosa $(P=0.01)$, Canna indica L. $(P=0.02)$, Dendranthema morifolium (Ramat.) Tzvelev $(P=0.04)$, Pelargonium hortorum Bailey $(P=0.02)$, Malva sinensis Cavan. $(P=0.02)$, and Pharbitis nil (L.) Choisy $(P=0.05)$.

\section{Selectivity of T. hawaiiensis to flower colors}

Simulations of different host flower colors attracted thrips differently. Female $T$. hawaiiensis showed clear preference rankings of white (D. caryophyllus: number of thrips $=30.0)>$ yellow $(T$. gesneriana: 23.5$)>$ purple $(H$. macrophylla: 15.3$)>$ pink (R. rugosa: 8.5$)(F=226.28$, $P<0.0001$, Fig. 1A). Male T. hawaiiensis showed a similar preference ranking as females for these four flower colors, except there was no significant difference between purple and yellow $(F=99.79, P<0.0001$, Fig. 1B).

\section{Behavioral response of $T$. hawaiiensis to the odor of different flowers}

When presented with different flower volatiles versus clean air (CA), T. hawaiiensis females showed significant preferences over CA for $H$. macrophylla $\left(\chi^{2}=37.79, d f=1\right.$, $P<0.001), T$. gesneriana $\left(\chi^{2}=39.19, d f=1, P<0.001\right), D$. caryophyllus $\left(\chi^{2}=6.23, d f=1, P=0.013\right)$ and $R$. rugosa $\left(\chi^{2}=4.92, d f=1, P=0.027\right)$ (Fig. 2).

When presented with pairs of the flower volatiles of the four plants, $T$. hawaiiensis females significantly preferred H. macrophylla to D. caryophyllus $\left(\chi^{2}=5.79, d f=1\right.$, $P=0.016)$ and to $R$. rugosa $\left(\chi^{2}=6.00, d f=1, P=0.014\right)$. Likewise, they preferred $T$. gesneriana to $D$. caryophyllus $\left(\chi^{2}=5.67, d f=1, P=0.017\right)$, and to $R$. rugosa $\left(\chi^{2}=4.41\right.$, $d f=1, P=0.036)$. They also preferred $D$. caryophyllus to $R$. rugosa $\left(\chi^{2}=4.09, d f=1, P=0.043\right)$. However, there was no significant difference in the responses to floral volatiles when presented with a choice between $H$. macrophylla and T. gesneriana $\left(\chi^{2}=1.85, d f=1, P=0.174\right)$.
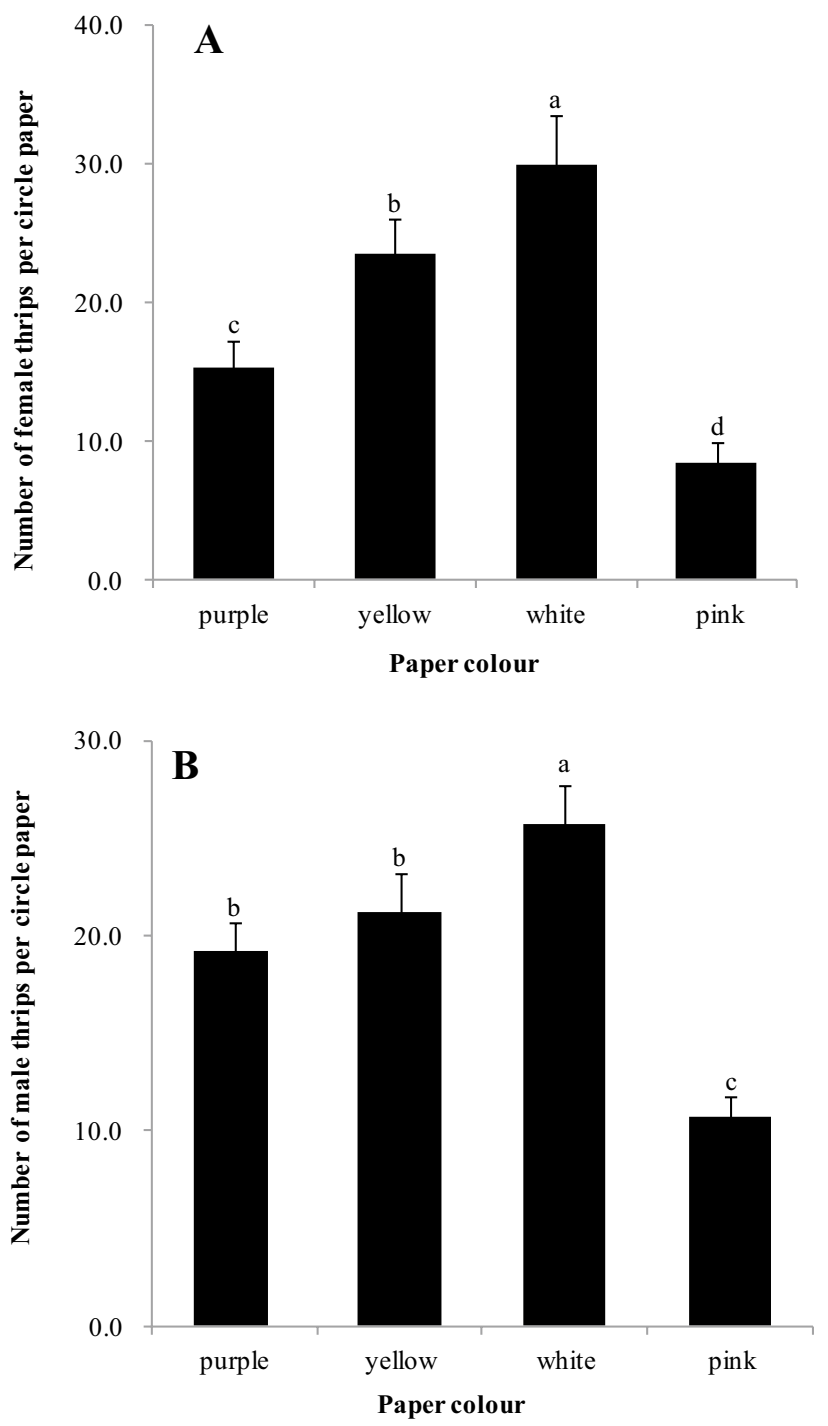

Fig. 1 Preference of T. hawaiiensis for different colors. Movement of thrips from a central release point onto different colored paper in quadrants in a Petri dish. A: female thrips; B: male thrips. Data are the mean \pm SE ( $n=4$ replicate experiments) for the number of thrips per color after $30 \mathrm{~min}$. In each Petri dish, 80 thrips were released per replicate. Different lowercase letters above bars indicate significant differences (one-way analysis of variance followed by Tukey's HSD test, $P<0.05$ )

\section{Development of thrips}

There were significant differences in the developmental time from egg to adult of $T$. hawaiiensis among the different host plant flowers $\left(F_{8,812}=48.99, P<0.01\right)$. Development required the least amount of time on $H$. macrophylla (Table 2). Development was over $12 \%$ faster on $H$. macrophylla than on $R$. rugosa. This was caused by the significantly different developmental durations of first instars $\left(F_{8,1011}=12.96, P=0.002\right)$ and second instars $\left(F_{8,899}=18.39, P=0.001\right)$. There were no significant 
Fig. 2 Olfactory responses of T. hawaiiensis females to the volatiles of different flowers. CA: clean air. Asterisks indicate highly significant $(* * P<0.01)$ and significant $(* P<0.05)$ differences in the selectivity of 60 adult $T$. hawaiiensis females between two odors ( $\chi^{2}$ test). n.s. indicates no significant difference $(P>0.05)$ in selectivity of $T$. hawaiiensis between two odors

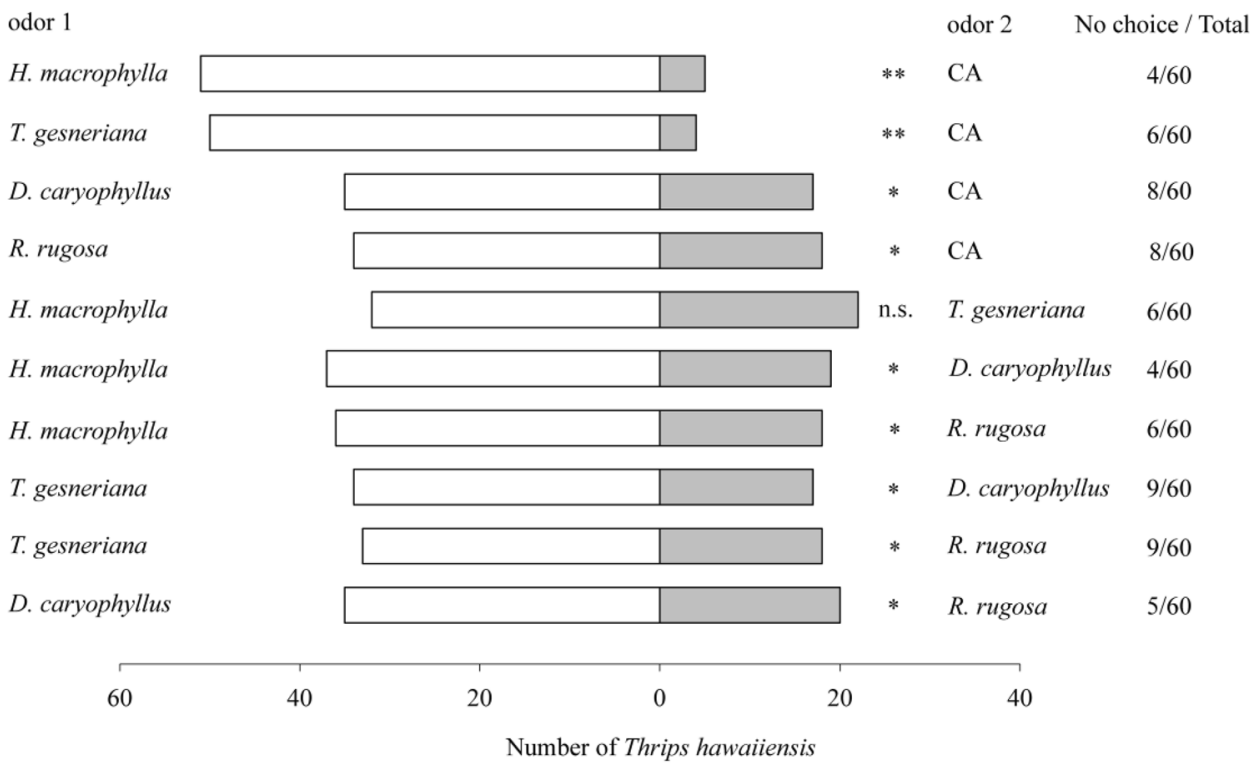

Table 2 Development periods (days $\pm \mathrm{SE}$ ) of $T$. hawaiiensis on different flowers

\begin{tabular}{lllll}
\hline Stage & Hydrangea macrophylla & Tulipa gesneriana & Dianthus caryophyllus & Rosa rugosa \\
\hline Egg & $2.08 \pm 0.02 \mathrm{a}(300)$ & $2.10 \pm 0.02 \mathrm{a}(300)$ & $2.12 \pm 0.02 \mathrm{a}(300)$ & $2.13 \pm 0.03 \mathrm{a}(300)$ \\
First instar & $2.03 \pm 0.02 \mathrm{c}(279)$ & $2.07 \pm 0.03 \mathrm{bc}(263)$ & $2.18 \pm 0.04 \mathrm{ab}(242)$ & $2.27 \pm 0.04 \mathrm{a}(227)$ \\
Second instar & $2.29 \pm 0.05 \mathrm{c}(250)$ & $2.38 \pm 0.05 \mathrm{bc}(234)$ & $2.26 \pm 0.06 \mathrm{ab}(216)$ & $2.79 \pm 0.05 \mathrm{a}(199)$ \\
Prepupa & $1.62 \pm 0.02 \mathrm{a}(236)$ & $1.67 \pm 0.04 \mathrm{a}(224)$ & $1.71 \pm 0.03 \mathrm{a}(203)$ & $1.77 \pm 0.04 \mathrm{a}(186)$ \\
Pupa & $1.57 \pm 0.04 \mathrm{a}(229)$ & $1.61 \pm 0.03 \mathrm{a}(214)$ & $1.66 \pm 0.04 \mathrm{a}(192)$ & $1.69 \pm 0.05 \mathrm{a}(177)$ \\
Egg to adult & $9.58 \pm 0.09 \mathrm{~d}(229)$ & $9.92 \pm 0.04 \mathrm{c}(214)$ & $10.35 \pm 0.07 \mathrm{~b}(192)$ & $10.75 \pm 0.08 \mathrm{a}(177)$ \\
\hline
\end{tabular}

Different lowercase letters in the same row indicate significant differences (one-way analysis of variance followed by Tukey's HSD test, $P<0.05$ ). Number of live insects at each developmental stage is shown in brackets differences among host plants for any of the non-feeding stages of immature thrips (Table 2).

\section{Survival of thrips}

Flower species significantly influenced the survival rates of T. hawaiiensis at the first instar $\left(F_{8,1011}=58.25, P<0.01\right)$, prepupa $\left(F_{8,849}=4.94, p=0.032\right)$, and from egg hatching to adult stages $\left(F_{8,812}=106.27, P<0.01\right)$ (Fig. 3). For the entire immature stage, the greatest survival rate of $T$. hawaiiensis was on $H$. macrophylla $(76.33 \%)$, followed by T. gesneriana (71.33\%), D. caryophyllus (64.00\%) and $R$. rugosa $(59.00 \%)$.

\section{Discussion}

Four important findings emerge from this study. First, the flowering host plants that were investigated could be classified at four different fitness levels for T. hawaiiensis. Second,
T. hawaiiensis showed significantly different responses to both the color and volatiles of four flower species, H. macrophylla, T. gesneriana, D. caryophyllus and $R$. rugosa, each of which represents one of the four fitness levels for $T$. hawaiiensis. Third, the olfactory preference of female thrips for the four flowers (H. macrophylla $\geq T$. gesneriana $>D$. caryophyllus $>R$. rugosa) was in accordance with behavior of $T$. hawaiiensis observed in the field, but the visual preference was not. Fourth, host plant significantly influenced the development of thrips: higher host fitness levels for thrips correlated with faster development and higher survival rate in thrips.

As euryphagous herbivorous insects, thrips show clearly different feeding preferences and population sizes among different host plants (Mound 2005). For T. hawaiiensis, based on the thrips collected from all the flowers in our sampling area, we identified 21 flower plants that were attacked by this pest species, and we classified the host plants at four different fitness levels for T. hawaiiensis based on its performance on these plants in the field. There were 14 herbaceous 
Fig. 3 Survival rates of different developmental stages of $T$. hawaiiensis on different flowers. Data are the mean $\pm S E$ for survival rate of $T$. hawaiiensis. Different lowercase letters above bars indicate significant differences (one-way analysis of variance followed by Tukey's HSD test, $P<0.05$ )

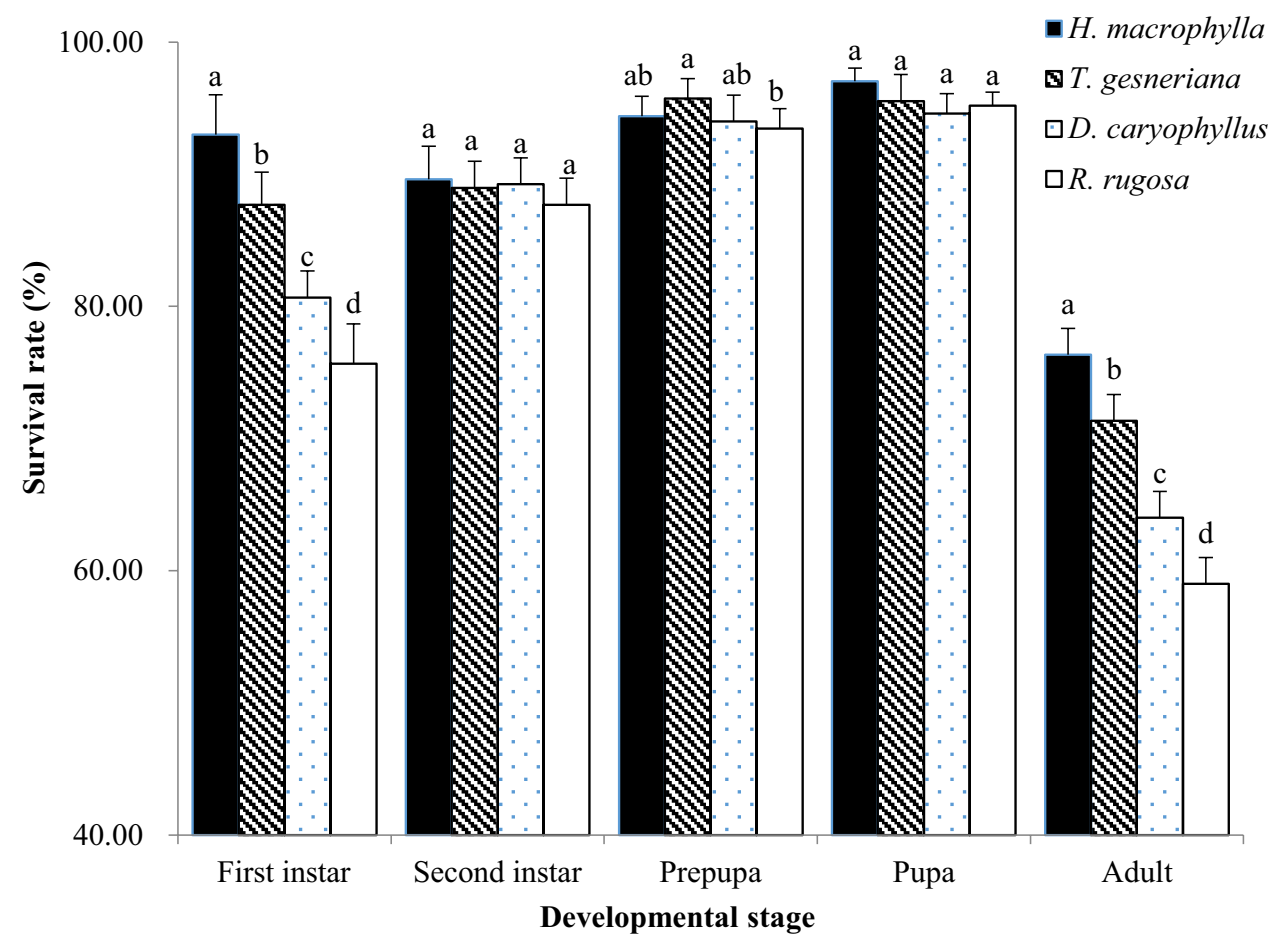

plants and 7 woody plants, representing 16 families, among the investigated flowering plant species. The different host plant preference of $T$. hawaiiensis may be caused by the different physicochemical properties among these host flowers (Qin and Wang 2001; Schoonhoven et al. 2005). It has been reported that the pupation rates of $F$. occidentalis in the soil and host plants can fluctuate depending on whether the plants are in the flowering or non-flowering stage. Buitenhuis and Shipp (2008) found that the proportion of F. occidentalis remaining on plants to pupate significantly increased in the presence of flowers, but a large proportion of thrips pupated in the soil. In the present study, we only counted the number of T. hawaiiensis pupa in plant flowers. Therefore, the number of T. hawaiiensis pupating in the soil is unknown. Further studies should consider the proportions of pupa in the soil and in flowers to determine whether this is a significant factor in the relationship between thrips and their hosts. Further studies should also evaluate the preferences of T. hawaiiensis among host plants at the non-flowering stage to better understand the interactions between thrips and hosts.

Visual and olfactory cues are important for thrips when searching for and selecting host plants. As reported extensively for $F$. occidentalis, thrips are attracted by the color and volatiles of host plants (Teulon et al. 1999; Mainali and Lim 2011; Cao et al. 2018, 2019; Avellaneda et al. 2019). We observed similar results for T. hawaiiensis in this study. Importantly, the olfactory preference rankings of female thrips for the four flowers tested in this study were in accordance with their fitness levels as hosts for the thrips. These results indicate that volatiles play an important role for $T$. hawaiiensis in selecting the most suitable host plant species for their offspring. This pattern was also observed in $F$. occidentalis in our previous studies (Cao et al. 2014, 2019). Therefore, it may be reasonable to pay more attention to the control of T. hawaiiensis on its preferred host plants because more thrips might aggregate on these plants, causing more serious damage. In addition, the volatiles from the preferred plant might act as aids for mating and oviposition, leading to more pest offspring (Groot et al. 2003; Olsson et al. 2006; $\mathrm{Xu}$ and Tarlings 2018).

There might be differences in host-discrimination mechanisms between the olfactory and visual responses of $T$. hawaiiensis, because its visual preference rankings were not in accordance with the host fitness level for the thrips. However, only simulated flowers using paper of fixed shape and size in different colors were tested in this study. The behavioral responses of $T$. hawaiiensis to flowers with natural color, size and shapes should be tested to evaluate comprehensively the visual preference of this thrips. For example, F. occidentalis has shown different preferences to different shapes of flowers in laboratory tests (Mainali and Lim 2011). Sticky traps with actual flower shapes enhance their attractiveness to thrips (Mainali and Lim 2008, 2010). Visual cues are only effective over relatively short distances and are not affected by air movement (Prokopy and Owens 1983), whereas olfactory cues can drift over a long distance via the wind (Cardé and Willis, 2008). Therefore, it is necessary to understand how olfactory and visual cues interact in the host selection process by herbivorous insects (Pinero 
et al. 2006; Goyret et al. 2007; Wenninger et al. 2009). Such knowledge will be helpful in aiding the management of pest thrips in the field (Vernon and Gillespie 1995; Teulon et al. 1999; Davidson et al. 2007; Mainali and Lim 2011).

Host plant species significantly influences the development and survival of T. hawaiiensis (Murai 2001; Zhang et al. 2014; Cao et al. 2018, 2019). In our study, development rate for $T$. hawaiiensis was the fastest on H. macrophylla, followed by $T$. gesneriana, then D. caryophyllus and was the slowest on $R$. rugosa. The survival rates (from high to low) of immature $T$. hawaiiensis on these flowers were in the same order. Based on these results, we conclude that T. hawaiiensis has faster development and greater survival rates on more attractive and suitable host plants. This phenomenon is also true for other thrips species, such as $F$. occidentalis, $F$. intonsa and Megalurothrips usitatus (Bagnall) (Li et al. 2015; Tang et al. 2015). Host plants with higher fitness levels should have better nutritional composition for the thrips, which would be beneficial for thrips development (Brown et al. 2003). The critical nutrients for the development or survival of T. hawaiiensis need further biochemical identification (Mollema and Cole 1996; Brodbeck et al. 2001).

Oviposition is another important factor in the host preference of insects, but we did not examine oviposition in this study. Characterizing oviposition and fecundity of $T$. hawaiiensis on different host plants would aid in interpreting the results of choice tests with $T$. hawaiiensis. In choice tests, Frankliniella fusca Hinds and. F. occidentalis have greater oviposition on more suitable larval hosts (Chaisuekul and Riley 2005). Therefore, the influence of the host plant species on the physiology of thrips should also be studied to explore their physiological adaptation to different plants (Veenstra et al. 1995; Kojima et al. 2010; Liu et al. 2017). By integrating such approaches, we will better understand the mechanisms of host plant selection, and how they result from behavioral and physiological responses to various plants. Then we will be able to take effective measures for improved and more sustainable management of $T$. hawaiiensis on preferred horticultural plants.

We did not determine the influence of pollen on the population development of thrips in this study. Previous studies have shown that pollen can affect the population development of $F$. occidentalis (Zhi et al. 2005; Riley et al. 2011), and that $F$. occidentalis shows olfactory preferences for volatiles from pine pollen (Abdullah et al. 2014). Thus, further research is required to determine whether the preferences of T. hawaiiensis for host plant flowers are related to the pollen. We note that other thrips species, for example, F. occidentalis, F. intonsa, and Thrips tabaci, were also detected in our study, and one or more of them coexisted with $T$. hawaiiensis in certain plant flowers. Therefore, the population performance of $T$. hawaiiensis may be influenced by interspecific competition with, or displacement by, other thrip species (Atakan and Uygur 2005, Paini et al. 2008, Northfield et al. 2011). These conditions should be taken into consideration to better assess and understand the host preferences of $T$. hawaiiensis.

\section{Author contribution statement}

YC, YLG and CL conceived and designed the research. YC, WC, LJW, and SYY conducted the experiments. YC and YLG analyzed the data. YC, SRR, GSG and WQZ wrote the manuscript. All of the authors read and approved the manuscript.

Acknowledgements We thank the National Natural Science Foundation of China (32060249), Natural Science Foundation from Guizhou Education Department ([2020]057), First-class Discipline Construction of Guizhou Province (XKTJ[2020]14), the Program for Academician Workstation in Guiyang University (20195605), the Training Project for High-Level Innovative Talents in Guizhou Province (No. 2016 [4020]), Discipline and Master's Site Construction Project of Guiyang University financed by Guiyang City (SH-2020), and National Innovation and Entrepreneurship Training Program for College Students (202010976006, 202010976023) for financial support.

\section{Declaration}

Conflict of interest The authors declare that they have no conflict of interest.

Human and animal rights This research did not involve any human participants and/or animals, only the flower thrips T. hawaiiensis.

Open Access This article is licensed under a Creative Commons Attribution 4.0 International License, which permits use, sharing, adaptation, distribution and reproduction in any medium or format, as long as you give appropriate credit to the original author(s) and the source, provide a link to the Creative Commons licence, and indicate if changes were made. The images or other third party material in this article are included in the article's Creative Commons licence, unless indicated otherwise in a credit line to the material. If material is not included in the article's Creative Commons licence and your intended use is not permitted by statutory regulation or exceeds the permitted use, you will need to obtain permission directly from the copyright holder. To view a copy of this licence, visit http://creativecommons.org/licenses/by/4.0/.

\section{References}

Abdullah ZS, Ficken KJ, Greenfield BPJ, Butt TM (2014) Innate responses to putative ancestral hosts: Is the attraction of western flower thrips to pine pollen a result of relict olfactory receptors? J Chem Ecol 40:534-540. https://doi.org/10.1007/ s10886-014-0450-0

Aliakbarpour H, Salmah MRC (2011) Seasonal abundance and spatial distribution of larval and adult thrips (Thysanoptera) on weed host plants in mango orchards in Penang, Malaysia. Appl Entomol Zool 2:185-194. https://doi.org/10.1007/s13355-011-0030-5 
Atakan E, Uygur S (2005) Winter and spring abundance of Frankliniella spp. and Thrips tabaci Lindeman (Thysan., Thripidae) on weed host plants in turkey. J Appl Entomol 1:17-26. https://doi. org/10.1111/j.1439-0418.2005.00918.x

Atakan E, Ölçülü M, Pehlivan S, Satar S (2015) A new thrips species recorded in Turkey: Thrips hawaiiensis (Morgan, 1913) (Thysanoptera: Thripidae). Türk Entomol Bült 2:77-84. https://doi.org/ 10.16969/teb.13634

Avellaneda J, Díaz M, Coy-Barrera E, Rodríguez D, Osorio C (2019) Rose volatile compounds allow the design of new control strategies for the western flower thrips (Frankliniella occidentalis). J Pest Sci. https://doi.org/10.1007/s10340-019-01131-7

Brodbeck BV, Stavisky J, Funderburk JE, Andersen PC, Olson SM (2001) Flower nitrogen status and populations of Frankliniella occidentalis feeding on Lycopersicon esculentum. Entomol Exp Appl 2:165-172. https://doi.org/10.1046/j.1570-7458.2001. 00814.x

Brown ASS, Simmonds MSJ, Blaney WM (2003) Relationship between nutritional composition of plant species and infestation levels of thrips. J Chem Ecol 12:2399-2409. https://doi. org/10.1023/a:1021471732625

Buitenhuis R, Shipp JL (2008) Influence of plant species and plant growth stage on Frankliniella occidentalis pupation behaviour in greenhouse ornamentals. J Appl Entomol 132(1):86-88. https://doi.org/10.1111/j.1439-0418.2007.01250.x

Byers JA (2006) Analysis of insect and plant colors in digital images using Java software on the internet. Ann Entomol Soc Am 99(5):865-874. https://doi.org/10.1603/0013-8746(2006) 99[865:AOIAPC]2.0.CO;2

Cai XM, Xu XX, Bian L, Luo ZX, Xin ZJ, Chen ZM (2015) Attractiveness of host volatiles combined with background visual cues to the tea leafhopper. Empoasca Vitis Entomol Exp Appl 157(3):291-299. https://doi.org/10.1111/eea.12364

Cao Y, Zhi JR, Cong CL, Margolies DC (2014) Olfactory cues used in host selection by Frankliniella occidentalis (Thysanoptera: Thripidae) in relation to host suitability. J Insect Behav 27(1):41-56. https://doi.org/10.1007/s10905-013-9405-5

Cao Y, Zhi JR, Zhang RZ, Li C, Liu Y, Lv ZY, Gao YL (2018) Different population performances of Frankliniella occidentalis and Thrips hawaiiensis on flowers of two horticultural plants. J Pest Sci 91:79-91. https://doi.org/10.1007/s10340-017-0887-3

Cao Y, Li C, Yang H, Li J, Li S, Wang YW, Gao YL (2019) Laboratory and field investigation on the orientation of Frankliniella occidentalis (Thysanoptera:Thripidae) to more suitable host plants driven by volatiles and component analysis of volatiles. Pest Manag Sci 75:598-606. https://doi.org/10.1002/ps.5223

Cao Y, Meng YL, Hong Yang H, Li J, Zhang GZ, Wang YW, Li C (2020) Preliminary study on behavioral responses of thrips hawaiiensis to volatiles of different flowers. J Henan Agric Sci 49(9):88-97

Cardé RT, Willis MA (2008) Navigational strategies used by insects to find distant, wind-borne sources of odor. J Chem Ecol 34:854-866. https://doi.org/10.1007/s10886-008-9484-5

Chaisuekul C, Riley DG (2005) Host plant, temperature, and photoperiod effects on ovipositional preference of Frankliniella occidentalis and Frankliniella fusca (Thysanoptera: Thripidae). J Econ Entomol 98:2107-2113. https://doi.org/10.1093/jee/98.6. 2107

Davidson MM, Butler RC, Winkler S, Tuelon DAJ (2007) Pyridine compounds increase trap capture of Frankliniella occidentalis (Pergande) in a covered crop. NZ Plant Prot 60:56-60. https:// doi.org/10.30843/nzpp.2007.60.4609

Fu BL, Qiu HY, Li Q, Tang LD, Zeng DQ, Liu K, Gao YL (2020) Flower injection of imidacloprid and spirotetramat: a novel tool for the management of banana thrips Thrips hawaiiensis. J Pest Sci. https://doi.org/10.1007/s10340-020-01209-7
Gaum WG, Giliomee JH, Pringle KL (1994) Life history and life tables of western flower thrips, Frankliniella occidentalis (Thysanoptera: Thripidae), on English cucumbers. Bull Entomol Res 84:219-224. https://doi.org/10.1017/S0007485300039729

Goldarazena A (2011) First record of Thrips hawaiiensis (Morgan, 1913) (Thysanoptera: Thripidae), an Asian pest thrips in Spain. Bull OEPP 41:170-173. https://doi.org/10.1111/j.1365-2338. 2011.02450.x

Goyret J, Markwell PM, Raguso RA (2007) The effect of decoupling olfactory and visual stimuli on the foraging behavior of Manduca sexta. J Exp Biol 210:1398-1405. https://doi.org/10.1242/ jeb.02752

Groot AT, Heijboer A, Visser JH, Dicke M (2003) Oviposition preference of Lygocoris pabulinus (het miridae) in relation to plants and conspecifics. J Appl Entomol 127(2):65-71. https://doi.org/ 10.1046/j.1439-0418.2003.00669.x

Huang Y, Cheng JS, Zhi JR, Yuan CM, Song QZ (2009) Investigation on thrips species on flowers in Guiyang, Guizhou Province. J Henan Agric Sci 6:93-96

Kojima W, Fujii T, Suwa M, Miyazawa M, Ishikawa Y (2010) Physiological adaptation of the Asian corn borer Ostrinia furnacalis to chemical defenses of its host plant, maize. J Insect Physiol 56(9):1349-1355. https://doi.org/10.1016/j.jinsphys.2010.04.021

Li WD, Zhang PJ, Zhang JM, Zhang ZJ, Huang F, Bei YW, Lin WC, Lu YB (2015) An evaluation of Frankliniella occidentalis (Thysanoptera: Thripidae) and Frankliniella intonsa (Thysanoptera: Thripidae) performance on different plant leaves based on life history characteristics. J Insect Sci 4:1-5. https://doi.org/10.1093/ jisesa/ieu 167

Liu JY, Qian L, Ke R, Chen XY, Li ZY, Gui FR (2017) Effects of elevated carbon dioxide on the activities of physiological enzymes in thrips Frankliniella occidentalis and $\mathrm{F}$ intonsa fed on different host plants. J Plant Prot 44(1):45-53. https://doi.org/10.1002/ps.5064

Mainali BP, Lim UT (2008) Evaluation of chrysanthemum flower model trap to attract two Frankliniella thrips (Thysanoptera: Thripidae). J Asia-Pac Entomol 11:171-174. https://doi.org/10. 1016/j.aspen.2008.07.003

Mainali BP, Lim UT (2010) Circular yellow sticky trap with black background enhances attraction of Frankliniella occidentalis (pergande) (thysanoptera: thripidae). Appl Entomol Zool 45(1):207213. https://doi.org/10.1303/aez.2010.207

Mainali BP, Lim UT (2011) Behavioral response of western flower thrips to visual and olfactory cues. J Insect Behav 24(6):436-446. https://doi.org/10.1007/s10905-011-9267-7

Mollema C, Cole RA (1996) Low aromatic amino acid concentrations in leaf proteins determine resistance to Frankliniella occidentalis in four vegetable crops. Entomol Exp Appl 78:325-333. https:// doi.org/10.1111/j.1570-7458.1996.tb00797.x

Mound LA (2005) Thysanoptera: diversity and interaction. Annu Rev Entomol 50:247-269. https://doi.org/10.1146/annurev.ento.49. 061802.123318

Murai T (2001) Development and reproductive capacity of Thrips hawaiiensis (Thysanoptera: Thripidae) and its potential as a major pest. Bull Entomol Res 91:193-198. https://doi.org/10. 1079/BER200186

Olsson POC, Anderbrant O, Löfstedt C (2006) Attraction and oviposition of Ephestia kuehniella induced by volatiles identified from chocolate products. Entomol Exp Appl 119(2):137-144. https:// doi.org/10.1111/j.1570-7458.2006.00401.x

Paini DR, Funderburk JE, Reitz SR (2008) Competitive exclusion of a worldwide invasive pest by a native. Quantifying competition between two phytophagous insects on two host plant species. J Anim Ecol 77:184-190. https://doi.org/10.1111/j.1365-2656. 2007.01324.x 
Pang BP, Bao ZS, Zhou XR, Chen JA (2004) Effects of host volatiles, leaf color, and cuticular trichomes on host selection by Liriomyza sativae Blanchard. Acta Ecol Sin 24(3):547-551

Pearsall IA (2000) Flower preference behaviour of western flower thrips in the Similkameen valley, British Columbia. Canada Entomol Exp Appl 95(3):303-313. https://doi.org/10.1046/j. 1570-7458.2000.00669.x

Pinero JC, Jacome I, Vargas R, Prokopy RJ (2006) Response of female melon fly, Bactrocera cucurbitae, to host-associated visual and olfactory stimuli. Entomol Exp Appl 121:261-269. https://doi. org/10.1111/j.1570-8703.2006.00485.x

Prokopy RJ, Owens EO (1983) Visual detection of plants by herbivorous insects. Annu Rev Entomol 28:337-364. https://doi.org/10. 1146/annurev.en.28.010183.002005

Qin JD, Wang CZ (2001) The relation of interaction between insects and plants to evolution. Acta Entomol Sin 44:360-365. https:// doi.org/10.1093/OBO/9780199830060-0193

Reynaud P, Balmès V, Pizzol J (2008) Thrips hawaiiensis (Morgan, 1913) (Thysanoptera: Thripidae), an Asian pest thrips now established in Europe. Bull OEPP 1:155-160. https://doi.org/10.1111/j. 1365-2338.2008.01201.x

Riley DG, Angelella GM, McPherson RM (2011) Pine pollen dehiscence relative to thrips population dynamics. Entomol Exp Appl 138:223-233. https://doi.org/10.1111/j.1570-7458.2011.01095.x

Schoonhoven LM, van Loon JJA, Dicke M (2005) Insect-plant biology. Oxford University, New York

Tang LD, Yan KL, Fu BL, Wu JH, Liu K, Lu YY (2015) The life table parameters of Megalurothrips usitatus (Thysanoptera: Thripidae) on four leguminous crops. Fla Entomol 98(2):620-625. https:// doi.org/10.1653/024.098.0235

Teulon DAJ, Hollister B, Butler RC, Cameron EA (1999) Colour and odour responses of flying western flower thrips: wind tunnel and greenhouse experiments. Entomol Exp Appl 93(1):9-19. https:// doi.org/10.1046/j.1570-7458.1999.00557.x

Tian T, Zhi JR, Lv ZY, Wen J, Cao Y (2017) Interactions between volatiles and the selectivity of Tetranychus urticae (Acari: Tetranychidae) to kidney beans infested by Frankliniella occidentalis (Thysanoptera: Thripidae). J Kansas Entomol Soc 90(4):313-322. https://doi.org/10.2317/16-13.1

Van Rijn PCJ, Mollema C, Steenhuis-Broers GM (1995) Comparative life history studies of Frankliniella occidentalis and Thrips tabaci (Thysanoptera: Thripidae) on cucumber. Bull Entomol Res 85:285-297. https://doi.org/10.1017/S0007485300034386
Veenstra KH, Pashley DP, Ottea JA (1995) Host-plant adaptation in fall armyworm host strains: comparison of food consumption, utilization, and detoxication enzyme activities. Ann Entomol Soc Am 88(1):80-91. https://doi.org/10.1093/aesa/88.1.80

Vernon RS, Gillespie DR (1990) Spectral responsiveness of Frankliniella occidentalis (Thysanoptera: Thripidae) determined by trap catches in greenhouses. Environ Entomol 19(5):1229-1241. https://doi.org/10.1093/ee/19.5.1229

Vernon RS, Gillespie DR (1995) Influence of trap shape, size, and background color on captures of Frankliniella occidentalis (Thysanoptera: Thripidae) in a cucumber greenhouse. J Econ Entomol 88(88):288-293. https://doi.org/10.1093/jee/88.2.288

Wenninger EJ, Stelinski LL, Hall DG (2009) Roles of olfactory cues, visual cues, and mating status in orientation of Diaphorina citri Kuwayama (Hemiptera: Psyllidae) to four different host plants. Environ Entomol 38:225-234. https://doi.org/10.1603/022.038. 0128

$\mathrm{Xu} \mathrm{H}$, Tarlings TCJ (2018) Plant volatiles as mate-finding cues for insects. Trends Plant Sci 23(2):100-111. https://doi.org/10.1016/j. tplants.2017.11.004

Yuan CM, Zhi JR, Cao Y, Ma H (2011) Selectivity of Frankliniella occidentalis to vegetable hosts. Acta Ecol Sin 31:1720-1726. https://doi.org/10.3724/SP.J.1011.2011.00383

Zhang ZJ, Wu QJ, Li XF, Zhang YJ, Xu BY, Zhu GR (2007) Life history of western flower thrips, Frankliniella occidentalis (Thysan., Thripidae), on five different vegetable leaves. J Appl Entomol 5:347-354. https://doi.org/10.1111/j.1439-0418.2007.01186.x

Zhang F, Fu BL, Liu K, Qiu HY, Wu W (2014) The effect of temperature on the development and survival of Thrips hawaiiensis (Morgan). Acta Ecol Sin 14:3895-3899. https://doi.org/10.5846/ stxb201212241855

Zhi JR, Fitch GK, Margolies DC, Nechols JR (2005) Apple pollen as a supplemental food for the western flower thrips, Frankliniella occidentalis: response of individuals and populations. Entomol Exp Appl 117:185-192. https://doi.org/10.1111/j.1570-7458. 2005.00351.x

Publisher's Note Springer Nature remains neutral with regard to jurisdictional claims in published maps and institutional affiliations. 